\section{From the Media Periodicals}

By Patrick Wright

BRITISH JOURNAL OF EDUCATION TECHNOLOGY,

14:3, October 1983 2 Mchridge, David \& McCormick, Bob, "China's television universities"
Barker, P.G. \& Singh, R., "A practical introduction to authoring for computer assisted instruction. Part 2: PILOT"

THE COMPUTING TEACHER, 11:4, November 1983

Cory, Sheila, "A 4-stage model of development for full Jarchow, Elaine M., "Teaching literature with the help of

microcomputers" "Calculus with muMath: implications
Heid, M. Kathleen, "Cal for curriculum reform"

THE COMPUTING TEACHER, 11:5, December/January 1983-83

Torgerson, Shirley, "Classroom management for Logo"

McCauley, Jim, "Kepler" "' programming"

Riordan, Tim, "Helping students with recursion: teaching strategies"
Moore, Margaret L., "A recursion excursion with a surprising discovery"
Bull, G. \& Tipps, S., "Problem spaces in a project-oriented Bull, G. \& Tipps, S.
Logo environment"

EDUCATIONAL COMMUNICATION AND TECHNOLOGY, 31:3, Fall 1983

Pressley, Michael, (et al.), "Mismatched pictures and chil-

dren's prose learning
Beck, Charles R., "Successive and simultaneous picture and passage formats: visual, tactual, and topical effects" tions in field independent and field dependent children's recall"

Levin, Joel R. (et al.), "Learning via mnemonic pictures: analysis of the presidential process"

\section{BOOK REVIEWS}

finally greater emphasis on lifetime

Finally, Masuda presents his seven-fold
eduction. which everyone pursues the possibilities of their own future by acting in a goaloriented way. However, it would be on a global scale in which multi-centered oluntary communities of citizens, par-

\title{
Mediography
}

Media on Instructional Design

EDUCATIONAL TECHNOLOGY, 23:10, October 1983 Goldes, Harold j., "Designing the human-computer interface" Noton, Priscilla, "Computer potentals and computer Tolbert, Patricia H \& Tolbert, Charles M. II. "Classroo Yeager, Douglas M., "Educational recordkeeping at a large corporation: the NCR system

Schwartz, Helen J., "Hypothesis testing with computerDerry, James O. \& Behnke, Ralph R., "Instantaneous feedback in the teaching/learning laborator

EDUCATIONAL TECHNOLOGY, 23:11, November 1983 Scanland, W. \& Slattery, D., "The impact of computer-based instruction upon teachers: two perspectives" Rockman, S., White D.J.D., \& Rampy, L., "Computers in the schools. the need for policy and action

Tiene, Drew \& Urakawa, Tomoji, "Japan's elementary television

Wileman, Ralph E. \& Gambill, Thomas G., "The neglected phase of instructional desig

Dettweiler, P.C., "Barriers to optimum use of educationa Borsnan, William J." "Use "driving force" to develo cohesive computer efforts in the schools"

Herschler, Michael S., "Use of computer simulation in teaching a college business course"

INSTRUCTIONAL INNOVATOR, 28:7, October 1983 Special issue: "High tech in higher education")
Lipson, Joseph I., "How to keep up-to-date with high Lipson, Joseph
technology"

MEDIA AND METHODS, 20:3, November 1983 Howe, Samuel F., "Interactive video"

Pantiel, Mindy \& Peterson, Becky, "School-friendly computers: the media specialists's key role" "Guide to education in a nuclear age"
"Educational computer buyer's guide"
By Nancy Lane

This issue's mediography deals with instructional design: arning, and the planning of instructional activities, student

COME TO THINK ABOUT IT Videorecording, TVO, 1979

6 - 30 min. programs, sd., col. motivating students.

COMMENTS ON EDUCATION Videorecording, NETCHE $197530 \mathrm{~min}$., sd., col.

A discussion of the state of education in the United States. With R. Glasser, F.S. Keller, W.J. Popham, B.F. Skinne Suppes.

CONCEPTS OF TEACHING Videorecording, NETCHE 198030 min., sd., col.

Designed to assist teachers in improving their teaching methods; the lesson looks at organization, participation

CURRICULUM DESIGN AND DEVELOPMENT SERIES, Motion Picture, OPENU/ITF, 1980, 12 programs - 25 min. ea., sd. col. This series looks at
using case studies.

EDUCATIONAL OBIECTIVES, Videorecording NETCHE 1972,3 programs $-30 \mathrm{~min}$. ea., sd., col. The role of objectives in planning for all aspects of the teaching/learning process is the subject here. Program titles are: Formulating and Use", "Planning Lessons", valuation of Achievement

EMERGING EDUCATIONAL PATTERNS, Motion Picture EDC 1971, 7 programs - 10 min. ea., sd., col.
Titles include: "Achieving Relevance with the Curriculum", and "Enriching the School Environment".

GETTING IT ALL TOGETHER, Motion Picture, MFFD/VEC $197229 \mathrm{~min}$. , sd., col.

An illustration of instructional management as a school-

HE HUMANITY OF TEACHING, Motion Picture, MFFD/ VEC, 197729 min., sd., col.

Educators discuss some major humanistic principles of

n a logical well developed sequence. He supposed cooperative nature of the does present some negative aspects such as the danger of an automated state or controlled society with the alienation of ests that if wecial decadence, but sugtion we will make the right choice and will not "succumb to the weaknesses" in the system. Unfortunately if one take into account man's shortcomings and competitive spirit, Masuda's argument is
Japanese culture is more suited to the "This book is useful for its optimistic icipating voluntarily in shared goals an the world". In general, the author presents his case Japanese-based discussion of a future society." It should be considered in conjunction with similar documents from

VOLUME 13, NUMBER 2, 1984
INNOVATIONS IN EDUCATION, Motion Picture, STNFRD, The titles in this series are: "Resource Center, "Stimuli For Innovation", "Team Teaching", "Technology in

STRUCTIONAL DEVELOPMENT - THE PEOPLE Motion Picture, MSU, 197215 min., sd., col. examines the problems encountered by educators seekin

CANADIAN JOURNAL OF EDUCATIONAL COMMUNICATION
NSTRUCTIONAL DEVELOPMENT - THE PROCESS Motion Picture, MSU, $197228 \mathrm{~min} .$, sd., col. Psychological media aids and campus resource services
are used to solve an instructional problem. Prerequisites for implementing an effective instructional development programs are outlined.

INSTRUCTIONAL DEVELOPMENT - THE RESULTS, Motion Picture, MSU, 197210 min., sd., col. Motion Picture, MSU, 197210 min., sd., col.
Examples of solutions to educational problems are shown here.

IS ANYONE OUT THERE LEARNING, Motion Picture, CBS/Marlin, 1978, 3 programs - 48 min. ea., sd., col. the situation, the causes, and the solutions.

LEARNING STYLES (INSTRUCTIONAL STRATEGIES) Videorecording, NETCHE, 197730 min., sd., col. This research has implications for instructiona

PERFORMANCE CURRICULUM I \& II, Motion picture

With Dr. Dwight Allen: the first program discusses issues in innovation, the second issues in organization.

SCIENCE TEACHING, Videorecording, NETCHE, 1971 3 programs -30 min. ea., sd., col.
Methods, Approaches, and Case this instructional series.

CONDARY CURRICULA, Videorecording, NETCHE, 1976, 2 programs -30 min. ea., sd., col. of the secondary education system and ways the problem ways to revitalize

THE SUBJECT IS LEARNING, Videorecording, TVO, 6 programs -30 min. ea., sd., col.

Numerous applications of cognitive learning theory as "Eglinton Public School", and "Talking About Learning".

TEACHER EFFECTIVENESS TRAINING, Motion picture MFFD/VEC, 197329 min., sd., col. Thomas Gordon's system of management and motivation described here.

TEACHING ROLE - A SERIES, Motion Picture, MFFD VEC, 1968, 12 programs -28 min. each., sd., col. Titles include: "Essential Methods of the Teaching -
Learning", "Creative Problem Solving", "Formulation of Learning",
Objectives".

THE TEACHING TRIAD, Motion Picture, AIMS/ITF, 1974

19 min., sd., col.
This film shows how instructional management can and should include all aspects of each student's life - class-
room, school, teachers, and parents. 